
ISSN : 2615-1995, E-ISSN : 2615-0654

J. Madani., Vol. 2, No. 1, Maret 2019 (35 - 48)

(C)2018 Lembaga Kajian Demokrasi

MADANI

dan Pemberdayaan Masyarakat (LKD-PM)

\title{
PENGARUH BUDAYA ORGANISASI, KOMPENSASI, DAN MOTIVASI TERHADAP KINERJA KARYAWAN PT MULTI BINTANG INDONESIA
}

\author{
Eko Sudarso \\ Fakultas Ekonomi, Universitas Pamulang \\ dosen02070@unpam.ac.id
}

\begin{abstract}
Abstrak
Tujuan dari penelitian ini adalah untuk menganalisis pengaruh budaya organisasi terhadap kinerja karyawan, menganalisis pengaruh kompensasi terhadap kinerja karyawan, menganalisis pengaruh motivasi terhadap kinerja karyawan, menganalisis pengaruh budaya organisasi, kompensasi dan motivasi secara bersama-sama terhadap kinerja karyawan di PT Multi Bintang Indonesia. Populasi dalam penelitian ini adalah karyawan PT Multi Bintang Indonesia Tahun 2015 sebanyak 60 orang. Adapun sampel penelitian ini sebanyak 60 orang. Teknik pengambilan sampel menggunakan metode sensus yaitu jumlah sampel merupakan seluruh populasi data ini diperoleh secara langsung dari sumber utama dan diperoleh melalui kuesioner yang diperoleh dari karyawan PT Multi Bintang Indonesia Tahun 2015. Adapun alat pengujian hipotesis menggunakan software SPSS 22. Dari hasil uji regresi didapatkan variabel budaya organisasi $\left(X_{1}\right)$ memiliki nilai beta yang paling besar yaitu 0,598 dengan signifikansi 0,000, diikuti oleh variabel kompensasi $\left(X_{2}\right)$ dengan nilai beta 0,239 dan signifikansi 0,013, selanjutnya motivasi $\left(X_{3}\right)$ dengan nilai beta 0,239 dengan signifikansi 0,026. Nilai $R$ Square menunjukkan nilai 0,797 atau 79,70\%, hal tersebut bisa diartikan bahwa 79,70\% kinerja karyawan di Multi Bintang Indonesia dapat dijelaskan oleh variabel budaya organisasi, kompensasi, dan motivasi sisanya sebesar 20,30\% dijelaskan oleh variabel-variabel lain. Kesimpulannya adalah kinerja karyawan PT Multi Bintang Indonesia dipengaruhi oleh budaya organisasi, kompensasi dan motivasi. Faktor yang paling dominan berpengaruh terhadap kinerja karyawan adalah budaya organisasi.
\end{abstract}

Kata Kunci : Budaya organisasi, Kompensasi, Motivasi, Kinerja

\begin{abstract}
The purpose of this research is to analyze the effect of organizational culture on employee performance, analyze the effect of compensation on employee performance, analyze the effect of motivation on employee performance, analyze the effect of organizational culture, compensation and motivation together on employee performance at PT Multi Bintang Indonesia. The population in this research were 60 employees of PT Multi Bintang Indonesia in 2015. The sample of this research was 60 peoples. The sampling technique uses the census method, census method is the number of samples is the entire population of this data obtained directly from the main source and obtained through a questionnaire obtained from employees of PT Multi Bintang Indonesia in 2015. The hypothesis testing tool uses SPSS 22 software. From the results of the regression test, the organizational culture variable $\left(X_{1}\right)$ has the highest beta value of 0.598 with a significance of 0,000 , followed by compensation variable $\left(X_{2}\right.$ with beta value 0.239 and significance 0.013 , then motivation $\left(X_{3}\right)$ with a beta value of 0.239 with a significance of 0.026 . The value of $R$ Square shows a value of 0.797 or $79.70 \%$, this can be interpreted that $79.70 \%$ of employee performance at Multi Bintang Indonesia can be explained by organizational culture variables, compensation, and motivation, the remaining $20.30 \%$ is explained by other variables. The conclusion is that the performance of PT Multi Bintang Indonesia's employees is influenced by organizational culture, compensation and motivation. The most dominant factor influencing employee performance is organizational culture.
\end{abstract}

Keywords : Organizational Culture, Compensation, Motivation, Performance 


\section{PENDAHULUAN}

\section{Latar Belakang}

Tidak ada lingkungan bisnis organisasi yang bersifat statis, karena semua pasti akan mengalami perubahan. Perubahan yang diakibatkan oleh keadaan lingkungan yang dinamis dan kompetitif tersebut akan membawa dampak pada perubahan yang lebih besar lagi. Tanpa adanya kompetensi yang didukung oleh sumber daya manusia yang handal, maka organisasi akan mengalami kesulitan untuk dapat bersaing dengan organisasi-organisasi lain.

Kinerja karyawan merupakan salah satu tolok ukur dari kinerja organisasi, sehingga dalam hal ini perlu selalu mengevaluasi prestasi kerja tersebut dalam rangka untuk mempertahankan atau meningkatkan kinerja organisasi dan sebaliknya prestasi kerja yang sudah baik harus dipertahankan atau bahkan selalu ditingkatkan.

Banyak hal yang mempengaruhi kinerja karyawan, antara lain kurangnya perhatian pada setiap masalah, kurangnya orientasi terhadap hasil yang akan dicapai, gaji dan upah yang diterima karyawan belum layak, tidak adilnya kesempatan yang diberikan ke semua karyawan, tidak adanya pengakuan atas prestasi, tempat kerja yang kurang nyaman, kuantitas kerja yang dihasilkan sedikit, dan tidak berkembangnya kreatifitas karyawan, dan hal itu menunjukkan masih rendahnya kinerja sebagian karyawan terhadap organisasi.

Dalam hal ini peneliti ingin mengetengahkan tiga faktor, yaitu faktor budaya organisasi, faktor kompensasi dan faktor motivasi. Pemilihan ini didasarkan pada kenyataan bahwa ketiga faktor tersebut paling sering muncul dalam teori yang membicarakan faktor-faktor yang berpengaruh terhadap kinerja karyawan.

Hubungan antara budaya organisasi dengan sukses atau gagalnya kinerja suatu organisasi diyakini oleh para ilmuwan perilaku organisasi dan manajemen serta sejumlah peneliti sangat erat hubungannya. Budaya organisasi diyakini merupakan faktor penentu utama terhadap kesuksesan kinerja organisasi. Keberhasilan suatu oganisasi untuk mengimplementasikan aspek-aspek atau nilai-nilai (values) budaya organisasinya dapat mendorong organisasi tersebut tumbuh dan berkembang secara berkelanjutan.

Kompensasi yang diberikan secara benar, akan berpengaruh pada para karyawan yang lebih terpuaskan dan termotivasi untuk mencapai sasaran-sasaran organisasi. Hasil penelitian Widyatmini dkk (2008:26) membuktikan bahwa kompensasi memiliki hubungan yang sangat signifikan terhadap kinerja karyawan, hubungan tersebut adalah positif, artinya semakin baik kompensasi yang diterima oleh karyawan maka kinerja karyawan juga semakin baik.
Dari uraian tersebut di atas dapat dikatakan bahwa motivasi adalah sebagai salah satu faktor pendorong prestasi kerja karyawan, yang harus mendapat perhatian khusus jika menghendaki kinerja karyawannya meningkat sehingga tujuan yang diharapkan bisa tercapai.

Penelitian ini mengambil obyek penelitian pada PT Multi Bintang Indonesia yang merupakan perusahaan minuman besar yang memiliki reputasi baik dan bertanggungjawab dengan portofolio merek bir dan minuman ringan terkemuka. Perusahaan ini pertama kali didirikan pada tahun 1929. Dengan berkembang pesatnya modernisasi peralatan industri, maka PT Multi Bintang Indonesia menggunakan alatalat produksi yang canggih pula, hal tersebut berdampak pada pengurangan jumlah karyawan yang saat ini hanya berjumlah 60 karyawan.

Dari hasil pra survei yang dilakukan peneliti dengan mewawancarai salah satu kepala bagian produksi PT Multi Bintang Indonesia diperoleh hasil sebagai berikut; karyawan sering absen dan disaat jam istirahat siang karyawan tidak kembali tepat pada waktunya, seharusnya jam 13.00 kenyataannya hingga 13.15 sampai 13.30 baru pada kembali dari jam istirahatnya. Kemudian diperoleh informasi juga bahwa karyawan bagian gudang tidak sungguh-sungguh menjalankan tugasnya, sehingga terjadi penundaan pengiriman barang. Kemudian pimpinan yang kurang tegas dalam mengatur bawahannya karena kurangnya rasa sosialisasi antara pimpinan dan bawahan, sehingga tidak adanya komunikasi yang baik. Kurangnya peraturan yang mengikat para karyawan juga menjadi salah satu kendala sehingga masalah kedisiplinan kurang bisa diterapkan dengan jelas. Kesemua hal tersebutlah yang semakin jelas berdampak pada kinerja yang tidak baik ke perusahaan.

Selain dari pihak manajemen, peneliti juga mewawancarai beberapa karyawan PT Multi Bintang Indonesia diperoleh hasil sebagai berikut; karyawan cenderung merasa tidak puas terhadap pekerjaan yang dijalaninya, hal ini dapat dirasakan oleh karyawan PT Multi Bintang Indonesia yang merasa kurang nyaman dengan rekan kerjanya sendiri. Hal ini juga dapat dilihat pada kurangnya loyalitas karyawan terhadap perusahaan, rendahnya disiplin, dan target produksi maupun penjualan yang telah ditetapkan perusahaan sering tidak tercapai. Selain itu kondisi pekerjaan, beban kerja, dan gaji atau upah yang diterima karyawan juga masih terlalu kecil.

Berdasarkan pada pernyataan-pernyataan di atas, maka penelitian ini mengambil judul penelitian yaitu" Pengaruh Budaya Organisasi, Kompensasi, dan Motivasi terhadap Kinerja Karyawan pada PT Multi Bintang Indonesia “. 


\section{Pembatasan Masalah}

Mengingat luasnya pembahasan tentang pengaruh kinerja pegawai, maka penulis membatasi penelitian ini pada pokok pertanyaan penelitian sebagai berikut:

1. Membatasi masalah yang ada khususnya di PT Multi Bintang Indonesia.

2. Membatasi masalah hanya tentang budaya organisasi, kompensasi dan motivasi terhadap kinerja karyawan di PT Multi Bintang Indonesia.

\section{METODE}

\section{Tempat dan Waktu Penelitian}

Penelitian ini dilakukan di PT Multi Bintang Indonesia Jl. Daan Mogot KM 19 Tangerang, Banten 15122. Penelitian dimulai dari bulan Juli 2015 dan berakhir pada bulan Desember 2015.

\section{Metode Penelitian}

Mengacu pada tujuan penelitian ini pada bab I yaitu untuk mengetahui manakah diantara variabel budaya organisasi, kompensasi, dan motivasi yang berpengaruh terhadap kinerja karyawan, maka penelitian ini menggunakan metode pendekatan kuantitatif dengan survei guna mengumpulkan data yang hasil analisisnya akan dihadirkan dalam bentuk angka-angka. Menurut Sugiyono (2008:13) Metode Kuantitatif adalah metode penelitian yang berlandaskan pada filsafat positivisme, digunakan untuk meneliti pada populasi atau sampel tertentu, teknik pengambilan sampel pada umumnya dilakukan secara random, pengumpulan data menggunakan instrumen penelitian, analisis data bersifat kuantitatif atau statistik dengan tujuan untuk menguji hipotesis yang telah ditetapkan.

Penelitian yang dilakukan dalam kegiatan ini adalah deskriptif. Tujuan dari penelitian deskriptif adalah untuk memperoleh gambaran tentang kondisi dari variabel budaya organisasi, kompensasi, motivasi, dan kinerja karyawan. Metode penelitian yang digunakan adalah explanatory survey method, yang bertujuan untuk mendiskripsikan maupun menguji adanya hubungan dan sebab akibat antara dua variabel atau lebih Edi Sukarjono (2012:101).

Metode survei dengan mengambil sampel dari suatu populasi dan menggunakan kuesioner sebagai alat pengumpul data yang utama, sehingga jenis penelitian yang digunakan adalah explanatory (penjelasan). Explanatory (penjelasan) adalah satu jenis riset konklusif yang tujuan utamanya adalah mendapatkan bukti mengenai hubungan sebab akibat atau hubungan kausal Malhotra (2009:100).

Metode penelitian pada dasarnya merupakan cara ilmiah untuk mendapatkan data dengan tujuan dan kegunaan tertentu. Empat kunci utama yang perlu diperhatikan dalam melakukan suatu penelitian adalah ilmiah (kegiatan penelitian didasarkan pada ciri-ciri keilmuan, yaitu rasional, empiris, dan sistematis), rasional (kegiatan penelitian dilakukan dengan cara-cara yang digunakan), empiris (cara-cara yang dilakukan dapat diamati oleh indera manuasia, sehingga orang lain dapat mengamati dan mngetahui cara-cara yang digunakan) dan sistematis (proses yang digunakan dalam penelitian itu menggunakan langkah-langkah tertentu yang bersifat logis).

Sedangkan menurut Sugiyono (2008:2) Metode penelitian merupakan cara ilmiah untuk mendapatkan data yang valid dengan tujuan dapat ditemukan, dibuktikan dan dikembangkan suatu pengetahuan sehingga pada gilirannya dapat digunakan untuk memahami, memecahkan dan mengantisifikasi masalah. Metode penelitian adalah alat-alat pengukuran untuk memandu urutanurutan bagaimana penelitian dilakukan untuk membantu agar dapat memperoleh data yang dikehendaki sesuai dengan permasalahan yang akan diteliti.

Penelitian ini jika dilihat dari dimensi waktu, merupakan penelitian cross sectional yaitu kegiatan penelitian yang dilakukan pada saat tertentu. Metode cross sectional adalah satu jenis rancangan riset yang terdiri dari pengumpulan informasi mengenai sampel tertentu dari elemen populasi hanya satu kali (pada saat ini) Maholtra (2009:95).

\section{Populasi dan Sampel}

\section{a. Populasi}

Populasi merupakan wilayah generalisasi yang terdiri atas: obyek, atau subyek yang mempunyai kualitas dan karateristik tertentu yang ditetapkan oleh peneliti untuk dipelajari dan kemudian ditarik kesimpulannya. Jadi populasi bukan hanya orang, tetapi obyek dan bendabenda alam yag lain Sugiyono (2012:115). Populasi juga bukan sekedar jumlah yang ada pada obyek atau subyek yang dipelajari, tetapi meliputi seluruh karakteristik atau sifat yang dimiliki oleh subyek atau obyek itu.

Bila populasi besar, dan peneliti tidak mungkin mempelajari semua yang ada pada populasi, misalnya karena keterbatasan dana, tenaga, dan waktu, maka dapat digunakan sampel yang diambil dari populasi tersebut. Apa yang dipelajari dari sampel tersebut, kesimpulannya, akan diberlakukan untuk populasi. Untuk itu sampel yang diambil dari populasi harus betul-betul representatif (mewakili).

Populasi dalam penelitian ini adalah karyawan PT Multi Bintang Indonesia dengan jumlah karyawan tetap per Desember 2015 adalah sebanyak 60 karyawan. 


\section{b. Sampel}

Karena jumlah karyawan PT Multi Bintang Indonesia adalah 60 karyawan, maka menurut Sugiyono (2012:126) haruslah digunakan teknik sampling jenuh. Sampling jenuh adalah teknik penentuan sampel bila semua anggota populasi digunakan sebagai sampel. Hal ini sering dilakukan bila jumlah populasi relatif kecil, kurang dari 100 orang. Istilah lain sampling jenuh adalah dimana semua anggota populasi dijadikan sampel.

\section{HASIL dan PEMBAHASAN \\ Hasil}

\section{Uji Kualitas Data}

\section{a. Uji Validitas}

Untuk mengolah uji validitas suatu data variabel penulis menggunakan korelasi Product Moment dengan bantuan program Software IBM SPSS (Statistical Program for Social Science) versi 22.00 for window yaitu dengan mengkorelasikan skor item dengan skor total sehingga diperoleh nilai $\mathrm{r}_{\text {hitung }}$ kemudian dibandingkan dengan $\mathrm{r}_{\text {tabel }}(\mathrm{df}$ $=\alpha, n-2)$. Jika nilai $\mathrm{r}_{\text {hitung }}$ lebih besar dari $\mathrm{r}_{\text {tabel }}$ dan nilai $r$ positif, maka butir pertanyaaan dinyatakan valid. Nilai $r$ tabel untuk 60 responden dengan taraf kesalahan 5\% sebesar 0,254. Adapun hasil uji validitas dalam penelitian ini dapat dilihat pada tabel berikut:

\begin{tabular}{|c|c|c|c|c|}
\hline No & Pernyataan & Nilai $_{\text {hitung }}$ & Nilai $r_{\text {tabel }}$ & Keterangan \\
\hline 1 & Kuesioner 1 & 0,681 & 0,254 & Valid \\
\hline 2 & Kuesioner 2 & 0,735 & 0,254 & Valid \\
\hline 3 & Kuesioner 3 & 0,726 & 0,254 & Valid \\
\hline 4 & Kuesioner 4 & 0,672 & 0,254 & Valid \\
\hline 5 & Kuesioner 5 & 0,584 & 0,254 & Valid \\
\hline 6 & Kuesioner 6 & 0,558 & 0,254 & Valid \\
\hline 7 & Kuesioner 7 & 0,726 & 0,254 & Valid \\
\hline 8 & Kuesioner 8 & 0,335 & 0,254 & Valid \\
\hline 9 & Kuesioner 9 & 0,464 & 0,254 & Valid \\
\hline 10 & Kuesioner 10 & 0,509 & 0,254 & Valid \\
\hline 11 & Kuesioner 11 & 0,673 & 0,254 & Valid \\
\hline 12 & Kuesioner 12 & 0,642 & 0,254 & Valid \\
\hline 13 & Kuesioner 13 & 0,459 & 0,254 & Valid \\
\hline
\end{tabular}

Dari hasil perhitungan kuisioner variabel budaya organisasi yang dijawab oleh responden yang berjumlah 60 orang dengan 13 pertanyaan. Didapatkan $\mathrm{r}_{\text {hitung }}$ lebih besar dari $\mathrm{r}^{\text {tabel }}$, maka seluruh pernyataan dalam kuisioner budaya organisasi dinyatakan valid.

\begin{tabular}{|c|c|c|c|c|}
\hline \multicolumn{5}{|c|}{ Tabel 2. Hasil Uji Validitas Variabel Kompensasi $\left(\mathbf{X}_{2}\right)$} \\
\hline No & Pernyataan & Nilai $r_{\text {hitung }}$ & Nilai $r_{\text {tabel }}$ & Keterangan \\
\hline 1 & Kuesioner 1 & 0,536 & 0,254 & Valid \\
\hline 2 & Kuesioner 2 & 0,559 & 0,254 & Valid \\
\hline
\end{tabular}

\begin{tabular}{|c|l|c|c|c|}
\hline 3 & Kuesioner 3 & 0,571 & 0,254 & Valid \\
\hline 4 & Kuesioner 4 & 0,671 & 0,254 & Valid \\
\hline 5 & Kuesioner 5 & 0,609 & 0,254 & Valid \\
\hline 6 & Kuesioner 6 & 0,751 & 0,254 & Valid \\
\hline 7 & Kuesioner 7 & 0,718 & 0,254 & Valid \\
\hline 8 & Kuesioner 8 & 0,567 & 0,254 & Valid \\
\hline 9 & Kuesioner 9 & 0,500 & 0,254 & Valid \\
\hline 10 & Kuesioner 10 & 0,586 & 0,254 & Valid \\
\hline 11 & Kuesioner 11 & 0,491 & 0,254 & Valid \\
\hline 12 & Kuesioner 12 & 0,467 & 0,254 & Valid \\
\hline 13 & Kuesioner 13 & 0,400 & 0,254 & Valid \\
\hline
\end{tabular}

Dari hasil perhitungan kuisioner variabel kompensasi yang dijawab oleh responden yang berjumlah 60 orang dengan 13 pertanyaan. Didapatkan $\mathrm{r}_{\text {hitung }}$ lebih besar dari $\mathrm{r}_{\text {tabel }}$ maka seluruh pernyataan dalam kuisioner kompensasi dinyatakan valid.

Tabel 3. Hasil Uji Validitas Variabel Motivasi $\left(\mathrm{X}_{3}\right)$

\begin{tabular}{|c|c|c|c|c|}
\hline No & Pernyataan & Nilai $r_{\text {hitung }}$ & Nilai $\mathrm{r}_{\text {tabel }}$ & Keterangan \\
\hline 1 & Kuesioner 1 & 0,557 & 0,254 & Valid \\
\hline 2 & Kuesioner 2 & 0,558 & 0,254 & Valid \\
\hline 3 & Kuesioner 3 & 0,636 & 0,254 & Valid \\
\hline 4 & Kuesioner 4 & 0,570 & 0,254 & Valid \\
\hline$\$$ & Kuesioner $\$$ & $0,60 \pm$ & 0,254 & Valid \\
\hline 6 & Kuesioner 8 & 0,808 & 0,254 & Valid \\
\hline 9 & Kuesioner 9 & 0,583 & 0,254 & Valid \\
\hline 10 & Kuesioner 10 & 0,428 & 0,254 & Valid \\
\hline 11 & Kuesioner 11 & 0,487 & 0,254 & Valid \\
\hline 12 & Kuesioner 12 & 0,424 & 0,254 & Valid \\
\hline 13 & Kuesioner 13 & 0,443 & 0,254 & Valid \\
\hline
\end{tabular}

Dari hasil perhitungan kuisioner variabel motivasi yang dijawab oleh responden yang berjumlah 60 orang dengan 13 pertanyaan. Didapatkan $\mathrm{r}_{\text {hitung }}$ lebih besar dari $\mathrm{r}_{\text {tabel }}$ maka seluruh pernyataan dalam kuisioner motivasi dinyatakan valid.

\begin{tabular}{|c|c|c|c|c|}
\hline \multicolumn{5}{|c|}{ Tabel 4. Hasil Uji Validitas Variabel Kinerja Karyawan (Y) } \\
\hline No & \multicolumn{1}{|c|}{ Pernyataan } & Nilai $_{\text {hitung }}$ & Nilai $_{\text {tabel }}$ & Keterangan \\
\hline 1 & Kuesioner 1 & 0,483 & 0,254 & Valid \\
\hline 2 & Kuesioner 2 & 0,625 & 0,254 & Valid \\
\hline 3 & Kuesioner 3 & 0,738 & 0,254 & Valid \\
\hline 4 & Kuesioner 4 & 0,624 & 0,254 & Valid \\
\hline 5 & Kuesioner 5 & 0,662 & 0,254 & Valid \\
\hline 6 & Kuesioner 6 & 0,613 & 0,254 & Valid \\
\hline 7 & Kuesioner 7 & 0,739 & 0,254 & Valid \\
\hline 8 & Kuesioner 8 & 0,758 & 0,254 & Valid \\
\hline 9 & Kuesioner 9 & 0,553 & 0,254 & Valid \\
\hline 10 & Kuesioner 10 & 0,792 & 0,254 & Valid \\
\hline 11 & Kuesioner 11 & 0,764 & 0,254 & Valid \\
\hline 12 & Kuesioner 12 & 0,508 & 0,254 & Valid \\
\hline 13 & Kuesioner 13 & 0,706 & 0,254 & Valid \\
\hline
\end{tabular}


Dari hasil perhitungan kuisioner variabel kinerja karyawan yang dijawab oleh responden yang berjumlah 60 orang dengan 13 pertanyaan. Didapatkan $r_{\text {hitung }}$ lebih besar dari $r_{\text {tabel }}$ maka seluruh pernyataan dalam kuisioner kinerja karyawan dinyatakan valid.

\section{b. Uji Realibilitas}

Suatu kuesioner dikatakan reliable atau handal jika jawaban responden terhadap pertanyaan adalah konsisten atau stabil dari waktu ke waktu. Uji realibilitas adalah tingkat kestabilan suatu alat pengukur dalam mengukur suatu gejala/kejadian.

Untuk mengolah uji reliabilitas maka digunakan software IBM SPSS versi 22.00 for windows, jika nilai Cronbach Alpha > 0.6 maka instrumen kuesioner dinyatakan reliabel.

Adapun hasil uji releabilitas untuk semua variabel penelitian ini dapat dilihat seperti tabel berikut:

\begin{tabular}{|l|c|c|c|}
\hline \multicolumn{4}{|c|}{ Tabel 5. Hasil Uji Reliabilitas } \\
Case Processing Summary \\
\hline \multirow{2}{*}{ Cases } & Valid & 60 & 100.0 \\
\cline { 2 - 4 } & Excluded $^{\text {a }}$ & 0 & .0 \\
\cline { 2 - 4 } & Total & 60 & 100.0 \\
\hline a. Listwise deletion based on all variables in the procedure. \\
\hline \multicolumn{3}{|c|}{ Reliability Statistics } \\
\hline \multicolumn{3}{|c|}{ N of Items } \\
\hline \multicolumn{2}{|c|}{ Cronbach's Alpha } & 4 \\
\hline
\end{tabular}

Hasil pertama adalah 'Case Processing Summary', yaitu menjelaskan tentang jumlah data yang valid untuk di proses dan data yang dikeluarkan serta presentasenya. Dapat diketahui bahwa data atau case yang valid berjumlah 60 dengan persentase $100 \%$ dan tidak ada data yang dikeluarkan (exclide).

Hasil kedua adalah 'Reliability Statistics', ini adalah hasil dari analisis reliability dengan teknik Cronbach Alpha. Dapat di ketahui nilai Cronbach Alpha adalah 0,915 karena nilai lebih dari 0,6 instrumen kuesioner dinyatakan reliabel.

\section{c. Uji Asumsi Klasik}

\section{1). Uji Normalitas}

Uji normalitas pada model regresi digunakan untuk menguji apakah nilai residual yang dihasilkan dari regresi terdistribusi secara normal atau tidak. Model regresi yang baik adalah yang memiliki nilai residual yang terdistribusi secara normal. Beberapa metode uji normalitas yaitu dengan melihat penyebaran data pada sumber diagonal pada grafik Normal $P$ - $P$ Plot of regression standardized residual atau dengan uji One Sample Kolmogorov Smirnov. Apabila Asymp.Sig > 0,05, maka data tersebut berdistribusi normal dan begitu juga sebaliknya. Untuk mengolah uji normalitas maka digunakan software IBM SPSS versi 22.00 for windows. Uji normalitas dapat dilihat pada tabel di bawah ini.

\begin{tabular}{|l|l|r|}
\hline \multicolumn{3}{|c|}{ Tabel 6. Hasil Uji Normalitas } \\
\hline \multicolumn{2}{|c|}{ One-Sample Kolmogorov-Smirnov Test } \\
\hline N & $\begin{array}{c}\text { Unstandardized } \\
\text { Residual }\end{array}$ \\
\hline Normal Parameters a,b & Mean & .0000000 \\
\hline & Std. Deviation & 1.98429324 \\
\hline Most Extreme & Absolute & .124 \\
\hline Differences & Positive & .124 \\
\hline \multicolumn{2}{|l|}{} & -.085 \\
\hline Test Statistic & Negative & .124 \\
\hline Asymp. Sig. (2-tailed) & & $.063^{c}$ \\
\hline $\begin{array}{l}\text { a. Test distribution is Normal. } \\
\text { b. Calculated from data. } \\
\text { c. Lilliefors Significance Correction. }\end{array}$ \\
\hline
\end{tabular}

Normal P.P Plot of Regression Standardized Residual

Dependent Variable: KinerjaKaryawan

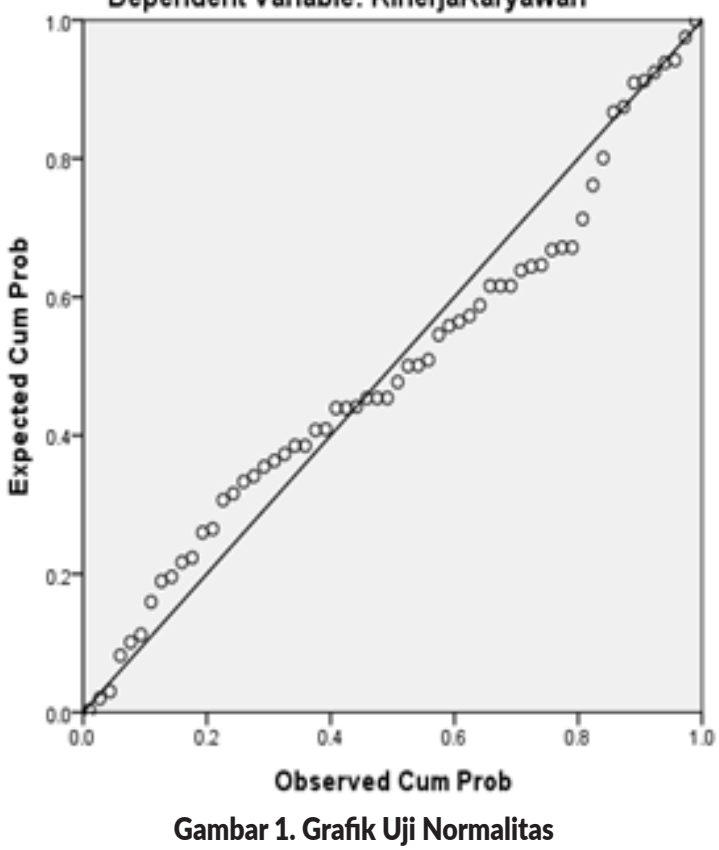

Dari output di atas dapat diketahui bahwa nilai signifikansi (Asymp.Sig 2-tailed) sebesar 0,063 . Karena signifikansi lebih dari $0,05(0,063$ $>0,05)$, maka nilai residual tersebut telah normal atau dapat dikatakan bahwa data tersebut terdistribusi normal. Sedangkan pada gambar grafik di atas diketahui bahwa titik-titik menyebar di sekitar garis dan mengikuti garis diagonal, maka nilai residual tersebut terdistribusi normal

\section{2). Uji Multikolineritas}

Uji multikolinearitas digunakan untuk mengetahui ada atau tidaknya penyimpangan 
asumsi klasik multikolinearitas yaitu adanya hubungan linear antar variabel independen dalam model regresi. Prasyarat yang harus terpenuhi dalam model regresi adalah tidak adanya multikolinearitas. Ada beberapa metode pengujian yang bisa digunakan diantaranya yaitu:

1. Dengan membandingkan nilai koefisien determinasi individual $\left(r_{2}\right)$ dengan nilai determinasi secara serentak $\left(\mathrm{R}_{2}\right)$.

2. Dengan melihat nilai tolerance dan inflation factor (VIF) pada model regresi.

Pada pembahasan ini akan dilakukan uji multikolinearitas dengan melihat nilai tolerance dan inflation factor (VIF) pada model regresi, cara untuk mengetahui ada atau tidaknya gejala multikoliniearitas anatara lain dengan melihat nilai tolerance dan inflation factor (VIF), apabila nilai VIF kurang dari 10 dan tolerance lebih dari 0.1 maka dinyatakan tidak terjadi multikolinieritas.

Uji multikolineritas pada penelitian ini dilakukan dengan matriks korelasi. Untuk mengolah uji multikolineritas menggunakan software IBM SPSS versi 22.00 for window.

\begin{tabular}{|c|c|c|c|c|c|c|c|c|}
\hline \multicolumn{9}{|c|}{ Tabel 7. Hasil Uji Multikolineritas } \\
\hline \multicolumn{9}{|c|}{ Coefficients $^{\mathrm{a}}$} \\
\hline \multirow{2}{*}{\multicolumn{2}{|c|}{ Model }} & \multicolumn{2}{|c|}{$\begin{array}{l}\text { Unstandardized } \\
\text { Coefficients }\end{array}$} & \multirow{2}{*}{$\begin{array}{c}\text { Standardized } \\
\text { Coefficients } \\
\text { Beta }\end{array}$} & \multirow[b]{2}{*}{ t } & \multirow[b]{2}{*}{ sig. } & \multicolumn{2}{|c|}{ Collinearity Statistics } \\
\hline & & B & $\begin{array}{l}\text { Std. } \\
\text { Error }\end{array}$ & & & & Tolerance & VIF \\
\hline \multirow[t]{4}{*}{1} & (Constant) & -3.467 & 4.065 & & .853 & .397 & & \\
\hline & $\begin{array}{l}\text { Buddaya } \\
\text { Organissai }\end{array}$ & .598 & .108 & .557 & 5.509 & .000 & .355 & 2.816 \\
\hline & Kompensasi & .239 & .093 & .225 & 2.576 & .013 & .475 & 2.103 \\
\hline & Motivasi & .239 & .104 & .202 & 2.294 & .026 & .468 & 2.139 \\
\hline
\end{tabular}

Dari hasil di atas dapat diketahui bahwa nilai tolerance ketiga variabel lebih dari 0.10 dan VIF kurang dari 10, maka dapat disimpulkan bahwa tidak terjadi multikolinieritas anatara variabel bebas.

\section{3). Uji Autokorelasi}

Autokorelasi merupakan korelasi antara anggota observasi yang disusun menurut waktu atau tempat. Model regresi yang baik seharusnya tidak terjadi autokorelasi. Metode penelitian ini menggunakan uji Durbin-Wetson (DW test). Pengambilan keputusan pada uji Durbin Watson sebagai berikut:

1) $\mathrm{DU}<\mathrm{DW}, 4-\mathrm{DU}$ maka Ho diterima, artinya tidak terjadi autokorelasi

2) $\mathrm{DW}<\mathrm{DL}$ atau DW $>4$-DL maka Ho di tolak, artinya terjadi autokorelasi

3) $\mathrm{DL}<\mathrm{DW}$ atau $4-\mathrm{DL}<\mathrm{DW}<4-\mathrm{DL}$, artinya tidak ada kepastian atau kesimpulan yang pasti.

\begin{tabular}{l}
\hline \multicolumn{7}{|c|}{ Tabel 8. Hasil Uji Autokorelasi } \\
\begin{tabular}{|c|c|c|c|c|c|}
\hline \multicolumn{1}{|c|}{ Model Summary } \\
\hline Model & $\mathrm{R}$ & R Square & $\begin{array}{l}\text { Adjusted } \\
\text { R Square }\end{array}$ & $\begin{array}{c}\text { Std. Error of } \\
\text { the Estimate }\end{array}$ & $\begin{array}{c}\text { Durbin- } \\
\text { Watson }\end{array}$ \\
\hline 1 & $.893^{\mathrm{a}}$ & .797 & .786 & 2.03675 & 2.019 \\
\hline
\end{tabular} \\
$\begin{array}{l}\text { a. Predictors: (Constant), Motivasi, Kompensasi, Budaya Organisasi } \\
\text { b. Dependent Variable: Kinerja Karyawan }\end{array}$ \\
\hline
\end{tabular}

Nilai DU dan DL dapat di peroleh dari tabel statistik Durbin Watson. Dengan $\mathrm{n}=60$, dan $\mathrm{k}=$ 3 didapat nilai $\mathrm{DL}=1,480$ dan $\mathrm{DU}=1,689$, jadi nilai 4 -DU $=2,311$ dan $4-\mathrm{DL}=2,52$. Dari hasil di atas dapat diketahui nilai Durbin Watson sebesar 2,019 karena nilai DW terletak antara DU dan 4-DU $(1,689<2,019<2,311)$ maka hasil uji Durbin Watson tidak ada autokorelasi pada model regresi.

\section{4). Uji Heteroskedastisitas}

Uji heteroskedastisitas digunakan untuk mengetahui ada atau tidaknya penyimpangan asumsi klasik heteroskedastisitas yaitu adanya ketidaksamaan varian dari residual untuk semua pengamatan yang lain pada model regresi. Prasyarat yang harus terpenuhi dalam model regresi adalah tidak adanya gejala heteroskedastisitas. Jika varians dari suatu residu atau dari suatu pengamatan lain tetap, maka disebut homokedastisitas. Model regresi yang baik adalah homokedastisitas atau tidak terjadi heteroskedastisitas. Salah satu cara untuk mendeteksi heteroskedastisitas adalah dengan menggunakan uji koefisien korelasi Rank Spearman yaitu mengkorelasikan antara absolute residual hasil regrisi dengan semua variabel bebas. Bila signifikansi hasil korelasi lebih kecil dari $0,05(5 \%)$ maka persamaan regresi tersebut mengandung heteroskedastisitas dan sebaliknya jika lebih besar dari 0,05 (5\%) berarti non heteroskedastisitas atau bersifat homokedastisitas. Hasil uji heteroskedastisitas Hasil uji heteroskedastisitas ditujukan pada tabel berikut:

\begin{tabular}{|c|c|c|c|c|c|c|}
\hline \multirow{2}{*}{\multicolumn{7}{|c|}{$\begin{array}{c}\text { Tabel 9. Hasil Uji Heteros } \\
\text { Correlations }\end{array}$}} \\
\hline & & & & & & \\
\hline & & & $\begin{array}{l}\text { Budaya } \\
\text { Organ- } \\
\text { isasi }\end{array}$ & $\begin{array}{l}\text { Kom- } \\
\text { pensasi }\end{array}$ & Motivasi & $\begin{array}{l}\text { Unstan- } \\
\text { dardized } \\
\text { Residual }\end{array}$ \\
\hline \multirow{7}{*}{$\begin{array}{l}\text { Spear- } \\
\text { man's } \\
\text { rh }\end{array}$} & \multirow[t]{3}{*}{$\begin{array}{l}\text { Budaya } \\
\text { Organisasi }\end{array}$} & $\begin{array}{l}\text { Correlation } \\
\text { Coefficient }\end{array}$ & 1.000 & $.535^{* *}$ & $.552^{* *}$ & -.138 \\
\hline & & Sig. (2-tailed) & . & .000 & .000 & .292 \\
\hline & & $\mathrm{N}$ & 60 & 60 & 60 & 60 \\
\hline & \multirow[t]{3}{*}{ Kompensasi } & $\begin{array}{l}\text { Correlation } \\
\text { Coefficient }\end{array}$ & $.535^{* *}$ & 1.000 & $.453^{* *}$ & -.057 \\
\hline & & Sig. (2-tailed) & .000 & . & .000 & .663 \\
\hline & & $\mathrm{N}$ & 60 & 60 & 60 & 60 \\
\hline & Motivasi & $\begin{array}{l}\text { Correlation } \\
\text { Coefficient }\end{array}$ & $.552^{* *}$ & $.453^{* *}$ & 1.000 & -.142 \\
\hline
\end{tabular}




\begin{tabular}{|l|l|l|r|r|r|r|}
\hline & Sig. (2-tailed) & .000 & .000 &. & .279 \\
\cline { 2 - 7 } & $\mathrm{N}$ & 60 & 60 & 60 & 60 \\
\cline { 2 - 7 } $\begin{array}{l}\text { Unstan- } \\
\text { dardized } \\
\text { Residual }\end{array}$ & $\begin{array}{l}\text { Correlation } \\
\text { Coefficient }\end{array}$ & -.138 & -.057 & -.142 & 1.000 \\
\cline { 2 - 7 } & Sig. (2-tailed) & .292 & .663 & .279 &. \\
\cline { 2 - 7 } & $\mathrm{N}$ & 60 & 60 & 60 & 60 \\
\hline
\end{tabular}

Dari output di atas dapat diketahui bahwa nilai korelasi ketiga variabel Budaya Organisasi, Kompensasi, dan Motivasi dengan Unstandardized Residual memiliki nilai signifikansi lebih dari 0,05. Karena signifikansi lebih dari 0,05 maka dapat disimpulkan bahwa tidak terjadi masalah heteroskedastisitas pada model regresi.

\section{Analisis Deskriptif Penelitian}

Jumlah sampel yang akan dijadikan responden dalam penelitian ini berjumlah 60 orang. Sesuai dengan tujuan analisis deskriptif yaitu untuk memberikan gambaran mengenai hasil penelitian secara umum, bagaimana karakteristik subyek penelitian sehubungan dengan variabelvariabel yang diteliti. Sebelum dilakukan analisis statistik terlebih dahulu pembobotan terhadap skor masing-masing variabel. Pembobotan ini dilakukan dengan memberikan skor total dengan jumlah item dari variabel yang dibobot melalui pertanyaan yang diberikan penulis dalam kuisioner maka dapat dideskriptifkan setiap variabel yang diteliti. Adapun Variabel yang diteliti adalah sebagai berikut :

\section{a. Variabel Budaya Organisasi $\left(\mathrm{X}_{1}\right)$}

Budaya organisasi merupakan sistem nilainilai, asumsi, kepercayaan, filsafat, kebiasaan organisasi dan yang lainnya yang di yakini anggota organisasi dan yang membedakan dengan organisasi lain. Diukur dengan indikator: memberi perhatian pada setiap masalah secara detail, berorientasi terhadap hasil yang akan dicapai, berorientasi kepada semua kepentingan karyawan, agresif dalam bekerja produktivitas tinggi, mempertahankan dan menjaga stabilitas kerja. Adapun penilaian responden atas variabel budaya organisasi dapat dipaparkan sebagai berikut:

Dari jawaban 60 responden terhadap variabel budaya organisasi dari 13 item pertanyaan, maka jawaban yang diperoleh kemudian di analisis oleh penulis dengan metode persentase, penulis menyimpulkan hasilnya seperti pada tabel di bawah ini:

Tabel 10. Hasil Kuisioner Variabel $\mathbf{X}_{1}$ Budaya Organisasi
\begin{tabular}{|c|c|c|c|c|c|c|}
\hline No & Pernyataan & SS & S & RG & TS & STS \\
\hline 1 & $\begin{array}{l}\text { Memberi perhatian pada } \\
\text { setiap masalah secara detail. }\end{array}$ & \multicolumn{7}{|c|}{} \\
\hline & $\begin{array}{l}\text { a. Jika ada masalah pekerjaan } \\
\text { dengan pihak lain dalam } \\
\text { perusahaan, diselesaikan } \\
\text { dengan win-win solution }\end{array}$ & 21 & 37 & 2 & 0 & 0 \\
\hline
\end{tabular}

\begin{tabular}{|c|c|c|c|c|c|c|}
\hline \multirow[t]{6}{*}{2} & \multirow{2}{*}{$\begin{array}{l}\text { Berorientasi terhadap hasil } \\
\text { yang akan dicapai. } \\
\text { a. Pihak manajemen } \\
\text { menyampaikan tujuan } \\
\text { perusahaan kepada } \\
\text { karyawan. }\end{array}$} & \multirow[b]{2}{*}{17} & \multirow[b]{2}{*}{42} & \multirow[b]{2}{*}{1} & \multirow[b]{2}{*}{0} & \multirow[b]{2}{*}{0} \\
\hline & & & & & & \\
\hline & $\begin{array}{l}\text { b. Perusahaan mempunyai } \\
\text { nilai-nilai yang menjadi } \\
\text { acuan saya dalam bekerja. }\end{array}$ & 12 & 43 & 5 & 0 & 0 \\
\hline & $\begin{array}{l}\text { c. Perusahaan } \\
\text { menginformasikan dengan } \\
\text { jelas ukuran keberhasilan } \\
\text { dalam pekerjaan saya. }\end{array}$ & 10 & 42 & 8 & 0 & 0 \\
\hline & $\begin{array}{l}\text { d. Karyawan mengerti } \\
\text { sasaran dan target } \\
\text { perusahaan dengan baik. }\end{array}$ & 11 & 42 & 7 & 0 & 0 \\
\hline & $\begin{array}{l}\text { e. Perusahaan memiliki } \\
\text { strategi yang jelas untuk } \\
\text { masa depan kami. }\end{array}$ & 15 & 43 & 2 & 0 & 0 \\
\hline \multirow[t]{4}{*}{3} & $\begin{array}{l}\text { Berorientasi kepada semua } \\
\text { kepentingan karyawan. }\end{array}$ & & & & & \\
\hline & $\begin{array}{l}\text { a. Gaji, imbalan, dan } \\
\text { penghargaan di } \\
\text { perusahaan ini didasarkan } \\
\text { oleh peraturan yang } \\
\text { berlaku. }\end{array}$ & 13 & 42 & 5 & 0 & 0 \\
\hline & $\begin{array}{l}\text { b. Perusahaan melakukan } \\
\text { acara darma wisata secara } \\
\text { rutin. }\end{array}$ & 18 & 41 & 1 & 0 & 0 \\
\hline & $\begin{array}{l}\text { c. Di perusahaan ini, } \\
\text { pekerjaan diselesaikan } \\
\text { dengan kerjasama tim } \\
\text { sesuai penugasan dari } \\
\text { atasan. }\end{array}$ & 4 & 50 & 5 & 1 & 0 \\
\hline \multirow[t]{3}{*}{4} & $\begin{array}{l}\text { Agresif dalam bekerja, } \\
\text { produktivitas tinggi. }\end{array}$ & & & & & \\
\hline & $\begin{array}{l}\text { a. Saya mengutamakan } \\
\text { kemajuan perusahaan } \\
\text { dengan menghindari } \\
\text { pekerjaan yang sia-sia. }\end{array}$ & 7 & 46 & 7 & 0 & 0 \\
\hline & $\begin{array}{l}\text { b. Perusahaan selalu } \\
\text { mendorong kami untuk } \\
\text { mengisi waktu dengan } \\
\text { kegiatan yang membawa } \\
\text { manfaat. }\end{array}$ & 8 & 39 & 13 & 0 & 0 \\
\hline \multirow[t]{3}{*}{5} & $\begin{array}{l}\text { Mempertahankan dan } \\
\text { menjaga stabilitas kerja. }\end{array}$ & & & & & \\
\hline & $\begin{array}{l}\text { a. Perusahaan } \\
\text { mensosialisasikan visi dan } \\
\text { misi kepada karyawan. }\end{array}$ & 9 & 39 & 12 & 0 & 0 \\
\hline & $\begin{array}{l}\text { b. Kemampuan kami sebagai } \\
\text { karyawan dipandang } \\
\text { sebagai sumber utama dari } \\
\text { keunggulan perusahaan. }\end{array}$ & 8 & 43 & 9 & 0 & 0 \\
\hline & JUMLAH & 153 & 549 & 77 & 1 & 0 \\
\hline
\end{tabular}

Dari hasil perhitungan variabel budaya organisasi yang dijawab oleh responden yang berjumlah 60 orang dengan 13 pertanyaan. Seluruh jawaban responden diambil dengan masingmasing skor butir lalu di bagi dengan total seluruh dari skor butir tersebut dikalikan $100 \%$. Maka didapatkan hasil sebagai berikut : SS (19,61\%), S (70,38\%), RG (9,87\%), TS (0,13\%), STS (0\%).

\section{b. Variabel Kompensasi $\left(\mathrm{X}_{2}\right)$}

Kompensasi adalah setiap bentuk pembayaran yang diberikan kepada karyawan sebagai pertukaran pekerjaan yang mereka berikan 
kepada majikannya. Diukur dengan indikator: adil, layak, gaji dan upah, intensif, fasilitas, serta tunjangan. Adapun penilaian responden atas variabel kompensasi dapat dipaparkan sebagai berikut :

Dari jawaban 60 responden terhadap variabel kompensasi dari 13 item pertanyaan, maka jawaban yang diperoleh kemudian di analisis oleh penulis dengan metode persentase, penulis menyimpulkan hasilnya seperti pada tabel di bawah ini:

\section{Tabel 11. Hasil Kuisioner Variabel $\mathbf{X}_{2}$ Kompensasi}

\begin{tabular}{|c|c|c|c|c|c|c|}
\hline No & Pernyataan & SS & $S$ & RG & TS & STS \\
\hline \multirow[t]{3}{*}{1} & Adil & & & & & \\
\hline & $\begin{array}{l}\text { a. Perusahaan memberikan } \\
\text { penghargaan bagi } \\
\text { karyawan yang bekerja } \\
\text { dengan baik }\end{array}$ & 17 & 40 & 2 & 1 & 0 \\
\hline & $\begin{array}{l}\text { b. Karyawan yang berkinerja } \\
\text { tinggi dibayar lebih tinggi } \\
\text { dibandingkan dengan } \\
\text { karyawan yang berkinerja } \\
\text { rendah. }\end{array}$ & 7 & 32 & 10 & 1 & 0 \\
\hline \multirow[t]{2}{*}{2} & Layak. & & & & & \\
\hline & $\begin{array}{l}\text { a. Saya menjalankan } \\
\text { pekerjaan dengan penuh } \\
\text { rasa tanggung jawab untuk } \\
\text { mendapatkan imbalan } \\
\text { yang layak. }\end{array}$ & 16 & 41 & 2 & 1 & 0 \\
\hline \multirow[t]{3}{*}{3} & Gaji dan Upah. & & & & & \\
\hline & $\begin{array}{l}\text { a. Saya merasa bahwa } \\
\text { motivasi dan semangat } \\
\text { kerja terpacu dengan gaji } \\
\text { yang saya terima saat ini. }\end{array}$ & 9 & 42 & 8 & 1 & 0 \\
\hline & $\begin{array}{l}\text { b. Perusahaan memberikan } \\
\text { kenaikan gaji bagi } \\
\text { karyawan yang dapat } \\
\text { bekerja dengan baik. }\end{array}$ & 11 & 43 & 5 & 1 & 0 \\
\hline \multirow[t]{3}{*}{4} & Intensif. & & & & & \\
\hline & $\begin{array}{l}\text { a. Bonus yang diberikan } \\
\text { perusahaan dapat } \\
\text { meningkatkan semangat } \\
\text { kerja karyawan. }\end{array}$ & 14 & 41 & 5 & 0 & 0 \\
\hline & $\begin{array}{l}\text { b. Perusahaan memberikan } \\
\text { penghargaan bagi } \\
\text { karyawan yang bekerja } \\
\text { dengan baik. }\end{array}$ & 7 & 40 & 13 & 0 & 0 \\
\hline \multirow[t]{4}{*}{5} & Fasilitas. & & & & & \\
\hline & $\begin{array}{l}\text { a. Pemberian asuransi } \\
\text { kesehatan membuat } \\
\text { karyawan merasa terjamin } \\
\text { bekerja di perusahaan ini. }\end{array}$ & 9 & 44 & 7 & 0 & 0 \\
\hline & $\begin{array}{l}\text { b. Pemberian asuransi } \\
\text { jaminan hari tua membuat } \\
\text { karyawan merasa terjamin } \\
\text { bekerja di perusahaan ini. }\end{array}$ & 11 & 42 & 6 & 1 & 0 \\
\hline & $\begin{array}{l}\text { c. Perusahaan memberikan } \\
\text { pelatihan kepada } \\
\text { karyawan agar } \\
\text { pengetahuan dan } \\
\text { keterampilan bekerja } \\
\text { karyawan meningkat. }\end{array}$ & 11 & 44 & 5 & 0 & 0 \\
\hline \multicolumn{7}{|l|}{6} \\
\hline & $\begin{array}{l}\text { a. Selain gaji, tunjangan yang } \\
\text { diberikan perusahaan } \\
\text { sudah layak dan } \\
\text { membantu karyawan. }\end{array}$ & 11 & 46 & 2 & 1 & 0 \\
\hline
\end{tabular}

\begin{tabular}{|c|c|c|c|c|c|c|}
\hline & $\begin{array}{l}\text { b. Setiap perayaan hari } \\
\text { keagamaan, karyawan } \\
\text { selalu mendapat THR yang } \\
\text { layak. }\end{array}$ & 13 & 45 & 2 & 0 & 0 \\
\hline $\begin{array}{l}\text { c. Perusahaan memberikan } \\
\text { penghargaan yang sesuai } \\
\text { bagi karyawan yang akan } \\
\text { mengakhiri masa kerja } \\
\text { (pensiun). }\end{array}$ & 8 & 45 & 6 & 1 & 0 \\
\hline JUMLAH & 144 & 544 & 73 & 8 & 0 \\
\hline
\end{tabular}

Dari hasil perhitungan variabel kompensasi yang dijawab oleh responden yang berjumlah 60 orang dengan 13 pertanyaan. Seluruh jawaban responden diambil dengan masing-masing skor butir lalu di bagi dengan total seluruh dari skor butir tersebut dikalikan $100 \%$. Maka didapatkan hasil sebagai berikut : SS (18,72\%), S (70,74\%), RG (9,49\%), TS (1,04\%), STS (0\%).

\section{c. Variabel Motivasi $\left(\mathrm{X}_{3}\right)$}

Motivasi adalah kebutuhan yang di stimulasi yang berorientasi kepada tujuan individu dalam mencapai rasa puas. Diukur dengan indikator: upah yang layak, kesempatan untuk maju, pengakuan sebagai individu, tempat kerja yang baik, penerimaan oleh kelompok, serta pengakuan atas prestasi. Adapun penilaian responden atas variabel kompensasi dapat dipaparkan sebagai berikut :

Dari jawaban 60 responden terhadap variabel motivasi dari 13 item pertanyaan, maka jawaban yang diperoleh kemudian di analisis oleh penulis dengan metode persentase, penulis menyimpulkan hasilnya seperti pada tabel di bawah ini:

\begin{tabular}{|c|c|c|c|c|c|c|}
\hline No & Pernyataan & SS & S & RG & TS & STS \\
\hline \multirow[t]{3}{*}{1} & Upah yang layak. & & & & & \\
\hline & $\begin{array}{l}\text { a. Saya bekerja semata-mata } \\
\text { hanya mencari upah yang } \\
\text { layak. }\end{array}$ & 4 & 46 & 9 & 1 & 0 \\
\hline & $\begin{array}{l}\text { b. Bila ada tugas kerja } \\
\text { lembur, saya merasa } \\
\text { termotivasi melakukan } \\
\text { pekerjaan tersebut dengan } \\
\text { sebaik-baiknya. }\end{array}$ & 5 & 49 & 4 & 2 & 0 \\
\hline \multirow[t]{3}{*}{2} & Kesempatan untuk maju. & & & & & \\
\hline & $\begin{array}{l}\text { a. Saya mempunyai keinginan } \\
\text { kuat untuk mendapatkan } \\
\text { jabatan yang lebih tinggi. }\end{array}$ & 12 & 43 & 5 & 0 & 0 \\
\hline & $\begin{array}{l}\text { b. Saya memiliki peluang } \\
\text { dan kesempatan untuk } \\
\text { mengembangkan } \\
\text { ketrampilan dan } \\
\text { kemampuan saya. }\end{array}$ & 14 & 41 & 5 & 0 & 0 \\
\hline \multirow[t]{2}{*}{3} & Pengakuan sebagai individu. & & & & & \\
\hline & $\begin{array}{l}\text { a. Saya merasa senang bila } \\
\text { pengabdian saya selama } \\
\text { bekerja di perusahaan } \\
\text { diakui oleh atasan. }\end{array}$ & 9 & 45 & 6 & 0 & 0 \\
\hline
\end{tabular}




\begin{tabular}{|c|c|c|c|c|c|c|}
\hline \multirow[t]{4}{*}{4} & \multicolumn{6}{|l|}{ Tempat kerja yang baik. } \\
\hline & $\begin{array}{l}\text { a. Hubungan kerja yang } \\
\text { baik dengan karyawan } \\
\text { lainnya dapat mendukung } \\
\text { kelancaran pekerjaan. }\end{array}$ & 10 & 49 & 0 & 1 & 0 \\
\hline & $\begin{array}{l}\text { b. Lingkungan kerja yang } \\
\text { baik akan meningkatkan } \\
\text { semangat kerja. }\end{array}$ & 15 & 42 & 3 & 0 & 0 \\
\hline & $\begin{array}{l}\text { c. Hubungan kerja antara } \\
\text { atasan dan bawahan } \\
\text { sangat baik dan tidak kaku. }\end{array}$ & 23 & 37 & 0 & 0 & 0 \\
\hline \multirow[t]{2}{*}{5} & \multicolumn{6}{|l|}{ Penerimaan oleh kelompok. } \\
\hline & $\begin{array}{l}\text { a. Saya merasa senang } \\
\text { karena karyawan di } \\
\text { perusahaan ini dapat } \\
\text { menerima saya sebagai } \\
\text { rekan kerja yang baik. }\end{array}$ & 14 & 42 & 4 & 0 & 0 \\
\hline \multirow[t]{2}{*}{6} & \multicolumn{6}{|l|}{ Pengakuan atas prestasi. } \\
\hline & $\begin{array}{l}\text { a. Pemberian penghargaan } \\
\text { bagi karyawan yang } \\
\text { berprestasi berdampak } \\
\text { besar terhadap kinerja } \\
\text { karyawan. }\end{array}$ & 11 & 45 & 4 & 0 & 0 \\
\hline & $\begin{array}{l}\text { b. Saya menginginkan orang } \\
\text { lain menghargai pekerjaan } \\
\text { saya. }\end{array}$ & 6 & 45 & 8 & 1 & 0 \\
\hline & $\begin{array}{l}\text { c. Atasan saya selalu } \\
\text { memberikan pujian apabila } \\
\text { saya menjalankan tugas } \\
\text { pekerjaan dengan hasil } \\
\text { memuaskan. }\end{array}$ & 5 & 49 & 6 & 0 & 0 \\
\hline & $\begin{array}{l}\text { d. Ide dan gagasan yang } \\
\text { disampaikan oleh bawahan } \\
\text { akan dinilai positif oleh } \\
\text { atasan. }\end{array}$ & 6 & 51 & 3 & 0 & 0 \\
\hline & JUMLAH & 134 & 584 & 57 & 5 & 0 \\
\hline
\end{tabular}

Dari hasil perhitungan variabel motivasi yang dijawab oleh responden yang berjumlah 60 orang dengan 13 pertanyaan. Seluruh jawaban responden diambil dengan masing-masing skor butir lalu di bagi dengan total seluruh dari skor butir tersebut dikalikan $100 \%$. Maka didapatkan hasil sebagai berikut : SS (17,18\%), S (74,87\%), RG (7,31\%), TS (0,64\%), STS (0\%).

\section{d. Variabel Kinerja Karyawan $(\mathrm{Y})$}

Keterampilan yang dimiliki oleh karyawan dalam melaksanakan tugas pekerjaannya yang meliputi kemampuan teknik, kemampuan konseptual, dan kemampuan hubungan interper sonal. Diukur dengan indikator: kuantitas hasil kerja, ketelitian, efisiensi, disiplin, inisiatif, tanggung jawab, kepemimpinan serta kreatifitas.

Dari jawaban 60 responden terhadap variabel kinerja karyawan dari 13 item pertanyaan, maka jawaban yang diperoleh kemudian di analisis oleh penulis dengan metode persentase, penulis menyimpulkan hasilnya seperti pada tabel di bawah ini:

\begin{tabular}{|c|c|c|c|c|c|c|}
\hline \multicolumn{7}{|c|}{ Tabel 13. Hasil Kuisioner Variabel Y Kinerja Karyawan } \\
\hline No & Pernyataan & SS & s & RG & TS & STS \\
\hline \multirow[t]{2}{*}{1} & Kuantitas hasil kerja. & & & & & \\
\hline & $\begin{array}{l}\text { a. Saya dapat menyelesaikan } \\
\text { pekerjaan sesuai dengan } \\
\text { jadwal target yang sudah } \\
\text { ditentukan. }\end{array}$ & 9 & 48 & 2 & 1 & 0 \\
\hline \multirow[t]{2}{*}{2} & Ketelitian. & & & & & \\
\hline & $\begin{array}{l}\text { a. Saya dapat menyelesaikan } \\
\text { pekerjaan dengan teliti } \\
\text { dan tepat sesuai yang } \\
\text { diharapkan. }\end{array}$ & 7 & 51 & 1 & 1 & 0 \\
\hline \multirow[t]{2}{*}{3} & Efisiensi. & & & & & \\
\hline & $\begin{array}{l}\text { a. Saya memiliki sikap kerja } \\
\text { yang menyenangkan } \\
\text { dan fokus pada tugas } \\
\text { pekerjaan. }\end{array}$ & 11 & 46 & 3 & 0 & 0 \\
\hline \multirow[t]{3}{*}{4} & Disiplin. & & & & & \\
\hline & $\begin{array}{l}\text { a. Kedisiplinan saya dapat } \\
\text { diterapkan dalam } \\
\text { menyelesaikan pekerjaan. }\end{array}$ & 7 & 46 & 7 & 0 & 0 \\
\hline & $\begin{array}{l}\text { b. Saya dapat menerima } \\
\text { kritikan dari rekan kerja } \\
\text { bila saya tidak disiplin } \\
\text { dalam melakukan } \\
\text { pekerjaan. }\end{array}$ & 7 & 38 & 14 & 1 & 0 \\
\hline \multirow[t]{2}{*}{5} & Inisiatif. & & & & & \\
\hline & $\begin{array}{l}\text { a. Saya memiliki } \\
\text { keterampilan teknis untuk } \\
\text { menyelesaikan pekerjaan. }\end{array}$ & 19 & 41 & 0 & 0 & 0 \\
\hline \multirow[t]{3}{*}{6} & Tanggung jawab. & & & & & \\
\hline & $\begin{array}{l}\text { a. Saya merasa mempunyai } \\
\text { tanggung jawab terhadap } \\
\text { terhadap pekerjaan yang } \\
\text { dibebankan kepada saya. }\end{array}$ & 12 & 46 & 2 & 1 & 0 \\
\hline & $\begin{array}{l}\text { b. Saya mampu } \\
\text { mempertanggung } \\
\text { jawabkan pekerjaan saya } \\
\text { kepada atasan. }\end{array}$ & 16 & 43 & 1 & 0 & 0 \\
\hline \multirow[t]{3}{*}{7} & Kepemimpinan. & & & & & \\
\hline & $\begin{array}{l}\text { a. Saya lebih } \\
\text { mengutamankan } \\
\text { kepentingan kelompok } \\
\text { dari pada kepentingan } \\
\text { pribadi dalam } \\
\text { menyelesaikan pekerjaan. }\end{array}$ & 18 & 34 & 6 & 2 & 0 \\
\hline & $\begin{array}{l}\text { b. Saya memiliki kemampuan } \\
\text { mengambil keputusan } \\
\text { dalam menyelesaikan } \\
\text { masalah pekerjaan. }\end{array}$ & 13 & 46 & 1 & 0 & 0 \\
\hline \multirow[t]{4}{*}{8} & Kreatifitas. & & & & & \\
\hline & $\begin{array}{l}\text { a. Saya memiliki } \\
\text { pengetahuan yang cukup } \\
\text { tentang tugas pekerjaan } \\
\text { yang diberikan kepada } \\
\text { saya. } \\
\end{array}$ & 13 & 43 & 4 & 0 & 0 \\
\hline & $\begin{array}{l}\text { b. Saya dapat bekerja dengan } \\
\text { baik dalam tim. }\end{array}$ & 14 & 41 & 5 & 0 & 0 \\
\hline & $\begin{array}{l}\text { c. Saya memiliki kreatifitas } \\
\text { untuk menyelesaikan } \\
\text { pekerjaan agar mencapai } \\
\text { hasil yang lebih baik. }\end{array}$ & 12 & 45 & 3 & 0 & 0 \\
\hline & JUMLAH & 158 & 568 & 49 & 6 & 0 \\
\hline
\end{tabular}

Dari hasil perhitungan variabel kinerja karyawan yang dijawab oleh responden yang berjumlah 60 orang dengan 13 pertanyaan. Seluruh 
jawaban responden diambil dengan masingmasing skor butir lalu di bagi dengan total seluruh dari skor butir tersebut dikalikan 100\%. Maka didapatkan hasil sebagai berikut: SS $(20,23 \%)$, S (72,73\%), RG (6,27\%), TS (0,77\%), STS (0\%).

\section{Analisis Regresi Berganda}

Regresi berganda digunakan untuk mengetahui seberapa besar pengaruh dari variabel bebas (Budaya Organisasi, Kompensasi, Motivasi) secara bersama-sama terhadap variabel terikat (Kinerja Pegawai). Sehingga dapat diketahui apakah ketiga variabel bebas tersebut berpengaruh positif atau negatif terhadap kinerja karyawan. Berdasarkan perhitungan regresi berganda menggunakan program SPSS versi 22.00 for windows di peroleh hasil sebagai berikut :

\begin{tabular}{|c|c|c|c|c|c|c|c|c|}
\hline \multicolumn{9}{|c|}{ Tabel 14. Hasil Uji Regresi Berganda } \\
\hline \multicolumn{9}{|c|}{ Coefficients ${ }^{\mathrm{a}}$} \\
\hline \multirow{2}{*}{\multicolumn{2}{|c|}{ Model }} & \multicolumn{2}{|c|}{$\begin{array}{l}\text { Unstandardized } \\
\text { Coefficients }\end{array}$} & \multirow{2}{*}{$\begin{array}{c}\text { Standardized } \\
\text { Coefficients } \\
\text { Beta }\end{array}$} & \multirow[b]{2}{*}{$t$} & \multirow[b]{2}{*}{ Sige. } & \multicolumn{2}{|c|}{ Collinearity Statistics } \\
\hline & & B & $\begin{array}{l}\text { Std. } \\
\text { Error }\end{array}$ & & & & Tolerance & VIF \\
\hline \multirow{4}{*}{1} & (Constant) & -3.467 & 4.065 & & .853 & .397 & & \\
\hline & $\begin{array}{l}\text { Budaya } \\
\text { Organissai }\end{array}$ & .598 & .108 & .557 & 5.509 & .000 & .355 & 2.816 \\
\hline & Kompensasi & .239 & .093 & .225 & 2.576 & .013 & .475 & 2.103 \\
\hline & Motivasi & .239 & .104 & .202 & 2.294 & .026 & .468 & 2.139 \\
\hline
\end{tabular}

Dari hasil perhitungan pada tabel diatas dapat disajikan ke dalam bentuk persamaan regresi standardized sebagai berikut :

$$
\begin{aligned}
\mathrm{Y}^{\prime} & =\mathrm{a}+\mathrm{b}_{1} \mathrm{X}_{1}+\mathrm{b}_{2} \mathrm{X}_{2}+\mathrm{b}_{3} \mathrm{X}_{3} \\
& =\mathrm{b}_{1} \mathrm{X}_{1}+\mathrm{b}_{2} \mathrm{X}_{2}+\mathrm{b}_{3} \mathrm{X}_{3}+\mathrm{a} \\
\mathrm{Y}^{\prime} & =0,598 \mathrm{X}_{1}+0,239 \mathrm{X}_{2}+0,239 \mathrm{X}_{3}+(-3,467) \\
& =0,598 \mathrm{X}_{1}+0,239 \mathrm{X}_{2}+0,239 \mathrm{X}_{3}-3,467
\end{aligned}
$$

Dimana :

$\mathrm{Y}^{\prime}=$ Kinerja Karyawan

$\mathrm{X}_{1}=$ Budaya Organisasi

$\mathrm{X}_{2}=$ Kompensasi

$\mathrm{X}_{3}=$ Motivasi

Berdasarkan analisis regresi, koefisien regresi $\mathrm{X}_{1}=0,598$ menunjukkan bahwa budaya organisasi mempunyai pengaruh positif terhadap kinerja karyawan, yang berarti setiap kenaikan satu poin, maka dapat di prediksi bahwa variabel kinerja karyawan ikut naik sebesar 0,598 dengan mengasumsikan variabel yang lain konstan.

Koefisien regresi $\mathrm{X}_{2}=0,239$ menunjukkan bahwa kompensasi mempunyai pengaruh positif terhadap kinerja karyawan, yang berarti setiap kenaikan satu poin, maka dapat di prediksi bahwa variabel kinerja karyawan ikut naik sebesar 0,239 dengan mengasumsikan variabel yang lain konstan.

Koefisien regresi $\mathrm{X}_{3}=0,239$ menunjukkan bahwa kompensasi mempunyai pengaruh positif terhadap kinerja karyawan, yang berarti setiap kenaikan satu poin, maka dapat di prediksi bahwa variabel kinerja karyawan ikut naik sebesar 0,239 dengan mengasumsikan variabel yang lain konstan.

\section{Pengujian Hipotesis}

a. Uji Parsial (Uji t)

Untuk menguji pengaruh budaya organisasi, kompensasi dan motivasi terhadap kinerja karyawan dapat digunakan uji statistik $\mathrm{t}$ (Uji t). Dengan menggunakan taraf signifikan 5\% $(0,05)$ 2 sisi dan derajat kebebasan (dk) dengan rumus : $\mathrm{df}=\mathrm{n}-\mathrm{k}-1$, dimana $\mathrm{n}$ adalah jumlah responden dan $\mathrm{k}$ adalah jumlah variabel independen yang diteliti. Kemudian membandingkan $\mathrm{t}$ hitung dengan $t$ tabel dengan kriteria:

1) Jika $t_{\text {hitung }}>t_{\text {tabel }}$ berarti $\mathrm{H}_{0}$ ditolak dan $\mathrm{Ha}$ diterima.

2) Jika $\mathrm{t}_{\text {hitung }} \leq \mathrm{t}_{\text {tabel }}$ berarti $\mathrm{H}_{0}$ diterima dan $\mathrm{Ha}$ ditolak.

Berdasar signifikamsi:

1) Jika signifikansi $>0,05$ maka $\mathrm{H}_{0}$ diterima.

2) Jika signifikansi $<0,05$ maka $\mathrm{H}_{0}$ ditolak

$\mathrm{t}_{\text {tabel }}$ dapat dilihat pada tabel statistik pada signifikansi $0,005 / 2=0,025$ dengan derajat kebebasan $\mathrm{df}=\mathrm{n}-\mathrm{k}-1$ atau $\mathrm{df}=60-3-1=54$, hasil untuk $\mathrm{t}_{\text {tabel }}$ sebesar 2,005

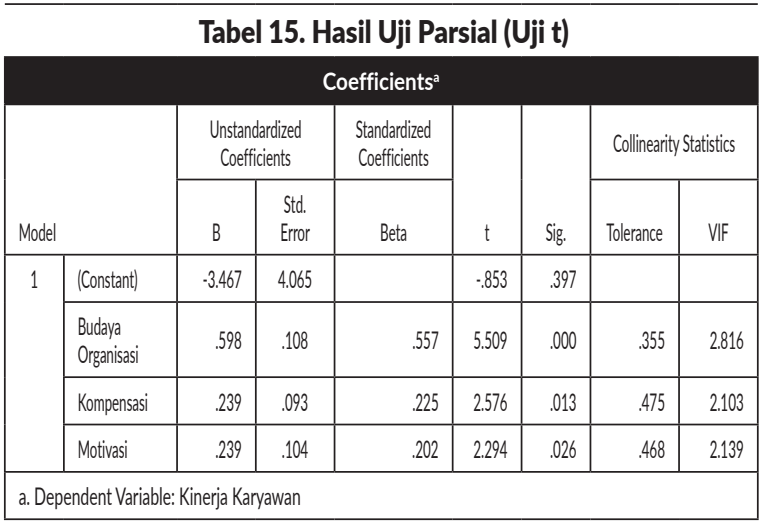

Untuk menguji hipotesis secara parsial digunakan uji $\mathrm{t}$ yaitu menguji secara parsial variabel bebas terhadap variabel terikat. Hasil perhitungan dapat dijelaskan sebagai berikut :

1) Uji $t$ terhadap variabel budaya organisasi $\left(\mathrm{X}_{1}\right)$ didapatkan $\mathrm{t}_{\text {hitung }}$ sebesar 5,509 dengan signifikan $\mathrm{t}$ sebesar 0,000 , karena $\mathrm{t}_{\text {hitung }}$ lebih besar darit $t_{\text {tabel }}(5,509>2,005)$ atau signifikansi lebih kecil dari $5 \%(0,000<0,05)$ maka secara parsial variabel budaya organisasi $\left(\mathrm{X}_{1}\right)$ berpengaruh signifikan terhadap variabel kinerja pegawai $(\mathrm{Y})$.

2) Uji t terhadap variabel kompensasi $\left(\mathrm{X}_{2}\right)$ didapatkan $\mathrm{t}_{\text {hitung }}$ sebesar 2,576 dengan signifikan $\mathrm{t}$ sebesar 0,013 , karena $\mathrm{t}_{\text {hitung }}$ lebih 
besar dari $\mathrm{t}_{\text {tabel }}(2,576>2,005)$ atau signifikansi t lebih kecil dari $5 \%(0,013<0,05)$ maka secara parsial variabel kompensasi $\left(\mathrm{X}_{2}\right)$ berpengaruh signifikan terhadap variabel kinerja pegawai (Y).

3) Uji t terhadap variabel motivasi $\left(\mathrm{X}_{3}\right)$ didapatkan $\mathrm{t}_{\text {hitung }}$ sebesar 2,294 dengan signifikan t sebesar 0,026, karena $t_{\text {hitung }}$ lebih besar dari $\mathrm{t}_{\text {tabel }}(2,294>2,005)$ atau signifikansi t lebih kecil dari $5 \%(0,026<0,05)$ maka secara parsial variabel gaya kepemimpinan $\left(\mathrm{X}_{3}\right)$ berpengaruh signifikan terhadap variabel kinerja pegawai $(\mathrm{Y})$.

\section{b. Uji Simultan (Uji F)}

Untuk menguji pengaruh budaya organisasi, kompensasi dan motivasi secara bersama-sama terhadap kinerja karyawan. Dalam penelitian ini digunakan uji statistik F (Uji F), dengan menggunakan taraf signifikansi $5 \%(0,05)$ dan derajat kebebasan (df) dengan rumus: $\mathrm{df}=\mathrm{n}-\mathrm{k}-1$, dimana $\mathrm{n}$ adalah jumlah responden dan $\mathrm{k}$ adalah jumlah variabel yang diteliti. Kemudian membandingkan $\mathrm{F}_{\text {hitung }}$ dengan $\mathrm{F}_{\text {tabel }}$ dengan kriteria:

1) Jika $\mathrm{F}_{\text {hitung }}>\mathrm{F}_{\text {tabel }}$ berarti $\mathrm{H}_{0}$ ditolak dan $\mathrm{Ha}$ diterima.

2) Jika $\mathrm{F}_{\text {hitung }} \leq \mathrm{F}_{\text {tabel }}$ berarti $\mathrm{H}_{0}$ diterima dan $\mathrm{Ha}$ ditolak.

$\mathrm{F}_{\text {tabel }}$ dapat dilihat pada tabel statistik pada tingkat signifikansi 0,05 dengan df 1 (jumlah variabel -1$)$, df $1=4-1=3$, dan df 2 ( $\mathrm{n}-\mathrm{k}-$ 1) atau $60-3-1=54$ ( $\mathrm{n}$ adalah jumlah data, dan $\mathrm{k}$ adalah jumlah variabel independen, hasil diperoleh untuk $\mathrm{F}_{\text {tabel }}$ sebesar 2,78

\begin{tabular}{|c|c|c|c|c|c|c|}
\hline \multicolumn{7}{|c|}{ Tabel 16. Hasil Uji Simultan (Uji F) } \\
\hline \multicolumn{7}{|c|}{ ANOVA $^{\mathrm{a}}$} \\
\hline \multicolumn{2}{|c|}{ Model } & $\begin{array}{l}\text { Sum of } \\
\text { Squares }\end{array}$ & df & $\begin{array}{l}\text { Mean } \\
\text { Square }\end{array}$ & $\mathrm{F}$ & Sig. \\
\hline 1 & Regression & 911.342 & 3 & 303.781 & 73.229 & $.000^{\mathrm{b}}$ \\
\hline & Residual & 232.308 & 56 & 4.148 & & \\
\hline & Total & 1143.650 & 59 & & & \\
\hline $\begin{array}{l}\text { a. Dep } \\
\text { b. Pre }\end{array}$ & $\begin{array}{l}\text { th Variab } \\
: \text { : Cons }\end{array}$ & $\begin{array}{l}\text { Kar } \\
\text { asi, }\end{array}$ & 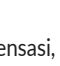 & 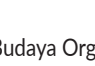 & & \\
\hline
\end{tabular}

Berdasarkan perhitungan dengan menggunakan program SPSS maka diperoleh nilai $\mathrm{F}_{\text {hitung }}$ $=73,229$ dan diperoleh nilai signifikansi 0,000, berdasarkan kriteria uji $\mathrm{F}$ dimana $\mathrm{F}_{\text {hitun }}>\mathrm{F}_{\text {tabel }}$ $(73,229>2,78)$ dan signifikansi $<0,005(0,000<$ 0,05), maka $\mathrm{H}_{0}$ ditolak, jadi dapat disimpulkan bahwa budaya organisasi, kompensasi, dan motivasi secara bersama-sama berpengaruh terhadap kinerja karyawan.

\section{Uji Determinasi}

\section{a. Uji Determinasi Simultan}

$\mathrm{R}$ Square $\left(\mathrm{R}^{2}\right)$ atau kuadrat dari $\mathrm{R}$ yaitu menunjukkan koefisien determinasi. Angka ini akan diubah kebentuk persentase, $\left(\mathrm{R}^{2}\right)$ digunakan untuk mengetahui seberapa besar persentase sumbangan pengaruh variabel independen secara serentak terhadap variabel dependen. Maksudnya secara serentak itu misalkan ada beberapa variabel independen $\left(\mathrm{X}_{1}, \mathrm{X}_{2}\right.$ dan seterusnya) mempengaruhi variabel dependen (Y). Koefisien determinasi dapat dilihat pada tabel Model Summary (hasil output olah data) $\mathrm{R}^{2}(R$ Square). Nilai $\mathrm{R}^{2}$ adalah sumbangan pengaruh variabel independen terhadap variabel dependen sedangkan dan biasa sisanya dipengaruhi oleh faktor lain yang tidak di teliti.

\begin{tabular}{|c|c|c|c|c|c|}
\hline \multicolumn{6}{|c|}{ Tabel 17. Hasil Uji Determinasi } \\
\hline \multicolumn{6}{|c|}{ Model Summary } \\
\hline Model & $\mathrm{R}$ & $\mathrm{R}$ Square & $\begin{array}{l}\text { Adjusted } \\
\text { R Square }\end{array}$ & $\begin{array}{l}\text { Std. Error of } \\
\text { the Estimate }\end{array}$ & $\begin{array}{l}\text { Durbin- } \\
\text { Watson }\end{array}$ \\
\hline 1 & $.893^{\mathrm{a}}$ & .797 & .786 & 2.03675 & 2.019 \\
\hline $\begin{array}{l}\text { a. Predict } \\
\text { b. Depenc }\end{array}$ & iable & $\begin{array}{l}\text { lasi, } \\
\text { Kar }\end{array}$ & & anisasi & \\
\hline
\end{tabular}

Dari tabel di atas dapat dilihat bahwa nilai $R$ Square sebesar 79,7\%. Hal ini menunjukkan bahwa variabel budaya organisasi, kompensasi dan motivasi mempengaruhi variabel kinerja karyawan di PT Multi Bintang Indonesia sebesar $79,7 \%$, sisanya $20,3 \%$ dipengaruhi oleh variabel lain.

\section{b. Uji Determinasi Parsial}

Untuk mengetahui seberapa besar pengaruh secara parsial per variabel X terhadap variabel $\mathrm{Y}$, maka dapat diketahui dengan cara mengkalikan nilai standardized coefficients beta dengan koefisien determinasi, yang mengacu pada hasil perhitungan dengan menggunakan SPSS 22 for window.

a. Uji determinasi variabel budaya organisasi terhadap kinerja karyawan yaitu 0,557 dikali 0,797 hasilnya 0,444 . Hal ini menunjukkan bahwa variabel budaya organisasi mempengaruhi variabel kinerja karyawan di PT Multi Bintang Indonesia sebesar 44,4\%.

b. Uji determinasi variabel kompensasi terhadap kinerja karyawan yaitu 0,225 dikali 0,797 hasilnya 0,179 . Hal ini menunjukkan bahwa variabel kompensasi mempengaruhi variabel kinerja karyawan di PT Multi Bintang Indonesia sebesar $17,9 \%$.

c. Uji determinasi variabel motivasi terhadap kinerja karyawan yaitu 0,202 dikali 0,797 hasilnya 0,161 . Hal ini menunjukkan bahwa variabel motivasi mempengaruhi variabel kinerja karyawan di PT Multi Bintang Indonesia sebesar $16,1 \%$.

\section{Pembahasan}

Berdasarkan permasalahan yang telah dianalisis dapat dilakukan pembahasan terhadap 
teori-teori yang telah dijelaskan dalam kerangka konseptual.

Hasil penelitian terbukti bahwa faktor budaya organisasi telah diterapkan dengan baik terbukti responden yang "sangat setuju" $19,61 \%$ dan "setuju" 70,38\%, ini terbukti salah satunya yaitu dengan adanya acara darma wisata yang dilakukan perusahaan terus-menerus tiap tahun tanpa terkecuali, sehingga karyawan merasa hilang sejenak kejenuhannya yang disebabkan oleh beban pekerjaan. Namun demikian masih ada karyawan yang "Ragu-ragu" sekitar 9,87\% respondens, sehingga harus dilakukan pengembangan budaya organisasi yang mengikuti jaman untuk menghasilkan kinerja dengan standar yang ditetapkan.

Kompensasi yang diterapkan oleh PT Multi Bintang Indonesia sudah sangat baik, yaitu responden yang "Sangat Setuju" sebanyak $18,72 \%$ dan yang "Setuju" 70,74\%, meskipun begitu ada karyawan yang masih "Ragu-ragu" sebesar 9,49\%, ini disebabkan mendapatkan THR yang mengacu kepada kebijakan pemerintah, sehingga karyawan yang sudah mengabdi lebih dari 5 tahun mendapatkan THR nya sama dengan karyawan yang masih baru /OJT (On the Job Training). Untuk meningkatkan kinerja karyawan sebaiknya PT Multi Bintang Indonesia menerapkan pemberian THR disesuaikan dengan masa kerja, ini akan memberikan rasa keadilan bagi karyawan yang sudah bekerja lebih lama.

Motivasi yang diterapkan oleh PT Multi Bintang Indonesia sudah sangat baik, yaitu responden yang "Sangat Setuju" sebanyak $17,18 \%$ dan yang "Setuju" 74,87\%, ini terbukti salah satunya yaitu dengan adanya pemberian penghargaan bagi karyawan yang berprestasi. Namun demikian masih ada karyawan yang "Ragu-ragu" sekitar 7,31\% responden, sehingga masih harus terus dilakukan motivasi terutama oleh pimpinan. Pemberian motivasi yang dilakukan melalui proses yang terus menerus dan berkesinambungan untuk menghasilkan kinerja dengan standar yag telah ditetapkan.

Dari hasil penelitian secara parsial analisis mengenai pengaruh budaya organisasi, kompensasi, motivasi terhadap kinerja karyawan sebagai berikut:

\section{Pengaruh Budaya Organisasi terhadap Kinerja Karyawan.}

Hasil pengujian hipotesis $\left(\mathrm{H}_{1}\right)$ telah membuktikan terdapat pengaruh antara budaya organisasi terhadap kinerja karyawan. Melalui hasil perhitungan yang telah dilakukan diperoleh nilai $t_{\text {hitung }}$ sebesar 5,509 dengan taraf signifikansi hasil sebesar 0,000 tersebut lebih kecil dari 0,05, dengan demikian $\mathrm{Ha}$ diterima dan $\mathrm{H}_{0}$ ditolak. Pengujian ini secara statistik membuktikan bahwa budaya organisasi berpengaruh positif terhadap kinerja karyawan artinya bahwa ada pengaruh antara variabel budaya organisasi terhadap kinerja karyawan di PT Multi Bintang Indonesia, hal ini disebabkan dengan adanya budaya organisasi yang baik maka kinerja karyawan PT Multi Bintang Indonesia pun akan menjadi baik.

\section{Pengaruh Kompensasi terhadap Kinerja Karyawan.}

Hasil pengujian hipotesis $\left(\mathrm{H}_{2}\right)$ telah membuktikan terdapat pengaruh antara kompensasi terhadap kinerja karyawan. Melalui hasil perhitungan yang telah dilakukan diperoleh nilai $\mathrm{t}_{\text {hitung }}$ sebesar 2,576 dengan taraf signifikansi hasil sebesar 0,013 tersebut lebih kecil dari 0,05, yang berarti bahwa hipotesis dalam penelitian ini menerima $\mathrm{Ha}$ dan menolak $\mathrm{H}_{0}$. Pengujian ini secara statistik membuktikan bahwa kompensasi berpengaruh positif terhadap kinerja karyawan artinya bahwa variabel kompensasi secara signifikan mempengaruhi kinerja karyawan di PT Multi Bintang Indonesia, hal ini disebabkan dengan adanya kompensasi yang baik maka kinerja karyawan PT Multi Bintang Indonesia akan baik.

\section{Pengaruh Motivasi terhadap Kinerja Karyawan.}

Hasil pengujian hipotesis $\left(\mathrm{H}_{3}\right)$ telah membuktikan terdapat pengaruh antara motivasi terhadap kinerja karyawan. Melalui hasil perhitungan yang telah dilakukan diperoleh nilai $\mathrm{t}_{\text {hitung }}$ sebesar 2,294 dengan taraf signifikansi hasil sebesar 0,026 tersebut lebih kecil dari 0,05, yang berarti bahwa hipotesis dalam penelitian ini menerima $\mathrm{Ha}$ dan menolak $\mathrm{H}_{0}$. Pengujian ini secara statistik membuktikan bahwa motivasi berpengaruh positif terhadap kinerja karyawan artinya bahwa variabel motivasi secara signifikan mempengaruhi kinerja karyawan di PT Multi Bintang Indonesia, hal ini disebabkan dengan adanya pemberian motivasi yang baik, maka kinerja karyawan PT Multi Bintang Indonesia akan baik.

\section{Pengaruh Budaya Organisasi, Kompensasi, Motivasi terhadap Kinerja Karyawan}

Secara simultan semua variabel bebas berpengaruh signifikan terhadap variabel terikat dengan nilai signifikansi $<0,05$. Pengaruh yang diberikan ketiga variabel bebas tersebut bersifat positif artinya semakin tinggi budaya organisasi, kompensasi dan motivasi maka mengakibatkan semakin tinggi pula kinerja karyawan yang dihasilkan. $F_{\text {tabel }}$ dapat dilihat pada tabel statistik pada tingkat signifikansi 0,05 dengan df 1 (jumlah variabel -1$)$, df $1=4-1=3$, dan df $2(\mathrm{n}-\mathrm{k}-$ 1) atau $60-3-1=54$ (n adalah jumlah data, 
dan $\mathrm{k}$ adalah jumlah variabel independen, hasil diperoleh untuk $\mathrm{F}_{\text {tabel }}$ sebesar 2,78.

Berdasarkan perhitungan dengan menggunakan program SPSS maka diperoleh nilai $\mathrm{F}_{\text {hitung }}$ $=73,229$ dan diperoleh nilai signifikansi 0,000 , berdasarkan kriteria uji $\mathrm{F}$ dimana $\mathrm{F}_{\text {hitun }}>\mathrm{F}_{\text {tabel }}$ $(73,229>2,78)$ dan signifikansi $<0,005(0,000<$ $0,05)$, maka $\mathrm{H}_{0}$ ditolak, jadi dapat disimpulkan bahwa budaya organisasi, kompensasi, dan motivasi secara bersama-sama berpengaruh terhadap kinerja karyawan.

\section{SIMPULAN}

Setelah peneliti melakukan penelitian dan membahas pokok permasalahan, maka pada bab terakhir ini, peneliti mencoba menarik kesimpulan dari pembahasan tersebut dan selanjutnya memberikan saran-saran yang diharapkan bagi perkembangan PT Multi Bintang Indonesia di masa yang akan datang.

\section{Kesimpulan}

Berdasarkan hasil penelitian dan pembahasan yang telah dilakukan dalam penelitian mengenai pengaruh budaya organisasi, kompensasi, dan motivasi terhadap kinerja karyawan, maka peneliti dapat menarik kesimpulan sebagai berikut:

1. Berdasarkan hasil analisis yang dilakukan maka variabel budaya organisasi memiliki pengaruh yang positif dan signifikan terhadap kinerja karyawan dengan nilai $t_{\text {hitung }}>$ $t$ tabel $(5,509>2,005)$ dengan nilai koefisien 0,598 . Maka budaya organisasi memiliki kontribusi $59,8 \%$ dan selebihnya 40,2\% dijelaskan oleh variabel variabel lain di luar penelitian ini.

2. Berdasarkan hasil analisis yang dilakukan maka variabel kompensasi memiliki pengaruh positif dan signifikan terhadap kinerja karyawan dengan nilai $\mathrm{t}_{\text {hitung }}>\mathrm{t}_{\text {tabel }}(2,576>$ 2,005 ) dan dengan nilai koefisien 0,239. Maka kompensasi memiliki kontribusi sebesar $23,9 \%$ dan selebihnya $76,1 \%$ dijelaskan oleh variabel lain di luar penelitian ini.

3. Berdasarkan hasil analisis yang dilakukan maka, variabel motivasi memiliki pengaruh positif dan signifikan terhadap kinerja karyawan dengan nilai $\mathrm{t}_{\text {hitung }}>\mathrm{t}_{\text {tabel }}(2,294>$ $2,005)$ dengan nilai koefisien 0,239. Maka motivasi memiliki kontribusi sebesar 23,9\% dan selebihnya $76,1 \%$ dijelaskan oleh variabel lain di luar penelitian ini.

4. Berdasarkan hasil uji simultan yang telah dilakukan maka variabel budaya organisasi, kompensasi, dan motivasi memiliki pengaruh yang positif dan signifikan terhadap kinerja karyawan dengan nilai koefisien determinasi
0,797 artinya data tersebut mengindikasikan bahwa budaya organisasi, kompensasi, dan motivasi secara bersama-sama mempunai kontribusi sebesar $79,7 \%$ terhadap kinerja karyawan dan selebihnya 20,3\% dipengaruhi oleh faktor lain yang tidak diteliti dalam penelitian ini. Hal ini sesuai dengan rumusan masalah yaitu budaya organisasi, kompensasi, dan motivasi berpengaruh terhadap kinerja karyawan (studi kasus pada PT Multi Bintang Indonesia) dan besarnya kontribusinya sebesar 79,7\% dipengaruhi oleh budaya organisasi, kompensasi dan motivasi sedangkan sisanya sebesar $20,3 \%$ dipengaruhi oleh faktor lain yang tidak diteliti di dalam penelitian ini.

\section{Saran}

Berdasarkan hasil penelitian yang telah dilakukan dan kesimpulan yang diperoleh di atas, maka peneliti dengan segala keterbatasan dan kemampuan yang dimiliki akan mencoba untuk memberikan suatu saran yang sekiranya dapat berguna bagi perusahaan yaitu antara lain:

1. PT Multi Bintang Indonesia perlu memperbaharui budaya organisasi sesuai perkembangan jaman lebih optimal dan terpadu agar dapat lebih meningkatkan kinerja karyawan.

2. PT Multi Bintang Indonesia perlu meningkatkan nilai kompensasi yang lebih optimal agar dapat lebih meningkatkan kinerja karyawan.

3. PT Multi Bintang Indonesia perlu meningkatkan motivasi yang lebih optimal agar dapat lebih meningkatkan kinerja karyawan.

4. Dapat dilanjutkan membuat penelitian di luar variabel bebas budaya organisasi, kompensasi, dan motivasi.

\section{DAFTAR PUSTAKA}

Arikunto, Suharsimi, 2010, Prosedur Penelitian "Suatu Pendekatan Praktik", Rineka Cipta, Jakarta.

Dessler. Gary, 2006, Manajemen Sumber Daya Manusia, Edisi ke sepuluh. PT. Intan Sejati, Klaten.

Dreher, George F, and Dougherty, Thomas W, 2001, Human Resource Strategy. A Behavioural Perspetive for The General Manager, McGraw Hill, inc, New York.

Duwi Priyatno, 2014, SPSS 22 Pengolahan Data Terperaktis, Andi, Yogyakarta.

Ghozali, I, 2005, Aplikasi Analisis Multivariate dengan Program SPSS, UNDIP, Semarang.

Gitosudarmo, I, Sudita, I., Nyoman, 2008, Perilaku Keorganisasian, BPFE, Yogyakarta

Hamid, 2003, Motivasi Kerja Karyawan, Armico, 
Bandung.

Hasibuan, M. S. P, 2007, Manajemen dasar, pengertian dan masalah, Bumi Aksara, Jakarta.

Hani. Handoko. 2003. Manajemen Sumber Daya Manusia, Salemba Empat, Jakarta.

Hasibuan, Malayu, 2003. Manajemen Sumber Daya Manusia, Erlangga, Jakarta.

Ivancevich, J. M. Konopaske R. dan Matteson M.T., 2005, Organizational Behaviorand Management. Seventh Edition, The McGrawHill Companies, New York.

Justin.T Sirait, 2006, Memahami Aspek-aspek Pengelolaan Sumber Daya Manusia dalam Organisasi, Gramedia Widiasarana, Jakarta.

Luthans, Fred, 2006, Perilaku Organisasi. jilid 10, ANDI, Jogyakarta.

Malthias, R. L. Dan Jakson, 2006, Human Resource Management, South -Western, Australia. Mangkunegara, A. A. A.P., 2000, Manajemen Sumber Daya Manusia Perusahaan, PT. Remaja Rosdakarya, Bandung.

Mathis, R. L., Jackson, J. H, 2011, Human Resource Management: Manajemen Sumber Daya Manusia. Edisi 10, Salemba Empat, Jakarta.

Munandar, Sunyoto, A., 2008, Psikologi Industri dan Organisasi, Penerbit Universitas Indonesia, Jakarta.

Mondy, Wayne. R., 2008, Manajemen Sumber Daya Manusia untuk Perusahaan, Rajawali Pers, Jakarta.

Nitisemito, 2001, Manajemen Personalia, Edisi kedua, Ghalia, Jakarta.

Notoatmodjo, Soekidjo, 2009, Pengembangan Sumber Daya Manusia, PT Rineka Cipta, Jakarta

Oemar, H, 2005, Pengembangan Sumber Daya Manusia: Manajemen Pelatihan Ketenagakerjaan (Pendekatan Terpadu), Bumi Aksara, Jakarta.

Rivai, Veithzal dan Sagala, E. J, 2009, Manajemen Sumber Daya Manusia untuk Perusahaan dari Teori ke Praktik, Penerbit Rajawali Pers, Jakarta.

Robbert L. Mathis \& John H. Jackson, 2006, Human Resource Management, Edisi Sepuluh, Salemba Empat, Jakarta.

Robbins, Stephen P. 2003, Perilaku Organisasi, Jilid I, Buku 1, Indeks, Jakarta.

Sastrohadiwiryo, S., 2002, Manajemen Tenaga Kerja Indonesia, edisi 2, PT. Bumi Aksara, Jakarta.

Siagian S. P., 2004, Manajemen Sumber Daya Manusia, Bumi Aksara, Jakarta.

Simamora, Henry, 2004, Manajemen Sumber Daya Manusia. Edisi Ke - 3, Bagian Penerbitan Sekolah Tinggi Ilmu Ekonomi YKPN, Yogyakarta.
Soekidjo, N, 2003, Pengembangan Sumber Daya Manusia, Rineka Cipta, Jakarta.

Sutrisno, Edy, 2011, Manajemen Sumber Daya Manusia, Kencana, Jakarta.

Sugiyono, Edy, 2013, Metode Penelitian Pendidikan Pendekatan Kuantitaif, Kualitatif, dan R\&D, Alfabeta, Bandung.

Sugiyono, 2002, Metode Penelitian Bisnis, Buku 1, Alfabeta, Bandung.

Veithzal, Rivai Fawzi, Basri, M. A., 2005, Performance Appraisal, PT. Raja Grafindo Persada, Jakarta.

Veithzal, Rivai dan Ella. Jauvani, 2010, Manajemen Sumber Daya Manusia untuk Perusahaan, PT. Raja Grafindo Persada, Jakarta.

Wijayanti, 2008, Manajemen, Mitra Cendekia Press, Yogyakarta.

Undang-Undang Nomor 13 tahun 2003 tentang Ketenagakerjaan. 